\title{
Specialization course in Neuroscience applied to education: a report of actions developed in a Physical Exercise and Nervous System Class
}

\author{
Curso de especialização em Neurociências aplicada à educação: relato das ações desenvolvidas na \\ disciplina de Exercício Físico e Sistema Nervoso \\ Curso de especialización en Neurociencias aplicadas a la educación: informe de acciones \\ desarrolladas en la disciplina del Ejercicio Físico y Sistema Nervioso
}

Received: 08/05/2021 | Reviewed: 08/10/2021 | Accept: 08/28/2021 | Published: 08/30/2021

\author{
Caroline Brandão Quines \\ ORCID: https://orcid.org/0000-0002-3818-1690 \\ Federal University of Pampa, Brazil \\ E-mail: carol_quines@hotmail.com \\ Gustavo Dias Ferreira \\ ORCID: https://orcid.org/0000-0001-5969-7250 \\ Federal University of Pelotas, Brazil \\ E-mail: gusdiasferreira@gmail.com \\ Mauren Assis de Souza \\ ORCID: https://orcid.org/0000-0001-8747-5751 \\ Federal University of Pampa, Brazil \\ E-mail: maurensouza@unipampa.edu.br
}

\begin{abstract}
Continuing education courses are important initiatives to facilitate the teacher comprehension about neuroscience. This paper is a report of actions developed in a Physical Exercise and Nervous System class that presented and discussed the physiological responses of physical activity (PA) practice on the Central Nervous System (CNS). The component was offered in two modules. Module I: PA and physiological adaptations; Module II: mechanisms of action of PA on CNS. The students demonstrated excellent engagement in the proposed activities and highlighted the importance of debating about neuroscience applied to Education. We considered a main positive outcome the interest of the students in applying the new knowledge in the schools where they work.
\end{abstract}

Keywords: Neuroscience applied to education; Neuroeducation; Physical exercise; Learning.

\section{Resumo}

A neurociência ainda tem um longo caminho a percorrer no ambiente escolar. Por esta razão, os cursos de educação continuada são iniciativas importantes. Este artigo é um relato das ações desenvolvidas na disciplina de Exercício Físico e Sistema Nervoso, que apresentou e discutiu as respostas fisiológicas da prática de exercício físico (EF) no Sistema Nervoso Central (SNC). O conteúdo foi oferecido de forma condensada dividido em dois módulos. Os alunos demonstraram excelente engajamento nas atividades propostas e destacaram a importância do debate sobre neurociências aplicada à educação. Consideramos como o fator mais positivo, o interesse dos alunos em aplicar os novos conhecimentos nas escolas onde trabalham.

Palavras-chave: Neurociências aplicada à educação; Neuroeducação; Exercício físico; Aprendizagem.

\section{Resumen}

La neurociencia todavía tiene un largo camino por recorrer en el ámbito escolar. Por esta razón, los cursos de educación continua son iniciativas importantes. Este artículo es un relato de las acciones desarrolladas en la disciplina de Ejercicio Físico y Sistema Nervioso, que presentó y discutió las respuestas fisiológicas de la práctica de ejercicio físico (EF) en el Sistema Nervioso Central (SNC). El contenido se ofreció en forma condensada dividida en dos módulos. Los estudiantes demostraron un excelente compromiso con las actividades propuestas y destacaron la importancia del debate sobre las neurociencias aplicadas a la educación. Consideramos como el factor más positivo, el interés de los estudiantes por aplicar los nuevos conocimientos en las escuelas donde trabajan.

Palabras clave: Neurociencias aplicadas a la educación; Neuroeducación; Ejercicio físico; Aprendizaje. 


\section{Introduction}

Educational neuroscience or neuroeducation is an emerging interdisciplinary field that seeks to translate research findings on neural mechanisms of learning to educational practice, and seems very promising for the future of education (Frith et al., 2011). Considering that neuroeducation is a basic science that studies how education changes the brain and the mechanisms that lead to behavioral change through education (Schwartz, 2015), it is necessary to make this knowledge accessible to teachers, especially from basic education, since this an important educational stage and is frequently the only formal education for a large number of young people in Brazil and other emergent countries (Marré, 2017).

Considerable progress has been made in understanding the neuronal mechanisms underlying competencies that are key components of formal education, such as memory, emotion, language, attention and executive functions (Arnsten \& Rubia, 2012; Pessoa, 2009). In this vein, it is important to note that significant advances have also been made in other domains that are relevant to education, such as the effects of PE on brain function (Hillman et al., 2008). These advances have aroused the interest of scientists and educators since such knowledge is essential for a new modeling in educational processes (Pickering \& HowardJones, 2007).

In this sense, the aim of the SCNAE is to integrate contents of neuroscience and education in order to enhance permanent formation especially of Basic Education teachers. Continuing education helps teachers expand their knowledge basis, bringing fresh inspiration to the classroom, and enhancing their careers (Mello, 2000).

One of the curricular components to achieve these goals was "Physical Exercise and Nervous System" that presented and discussed the physiological responses of the CNS resulting from the practice of PE and their effects on memory and motor learning, as well as myths about physical exercise and neurological diseases. The Brazilian legislation says that Physical Education is a compulsory curricular component of Basic Education for Children (LDB 9394/96), however, the person in charge of the activities related to this curricular component in public schools is the general teacher (pedagogue), not the specific Physical Education teacher. Hence this curricular component is important to draw attention to those responsible for teaching children on how exercise can aid in the learning processes of schoolchildren.

Understanding how physical exercise modulates the brain and cognitive functions can become a facilitator for teachers to plan activities that explore the full potential of students (Hillman et al., 2008). The aim of this work is to report how the "Physical Exercise and Central Nervous System" component, which is part of a SCNAE, offered by the Federal University of Pampa (Brazil-RS), was developed. In addition, it also aims to report the perception of teachers in charge of the discipline on the impact of this component for students. Disseminating actions in the field of neuroeducation is important for both educators and neuroscientists, and these actions can be implemented in other universities worldwide.

\section{Literature Review: neuroscience, physical exercise and impact on teaching}

According to Rato et al. (Rato et al., 2013), the biggest obstacle for neuroscience and education to converge is the existence of neuromyths. Teachers who have their educational practice based on neuromyths end up contributing to the dissemination of misinformation, which spreads not only among students and their families but also among teachers themselves, creating a vicious cycle (Arce et al., 2017; Howard-Jones, 2014).

In this sense, physical exercise presents itself as a relevant tool for the field of education. In general, people know the effects of PE for general health, however, a large number are unaware that PE can also help increase reasoning skills and be used as a tool in the classroom to improve learning, memory and focus (Mandolesi et al., 2018). Studies have shown that physical exercise has a positive influence on the processes of memory, attention, reaction time, as well as school performance (Chaddock et al., 2011), and it should be taken into consideration that school-aged children may have cognitive benefits in participating in 
physical activities (Sibley \& Etnier, 2003). In addition, exercise has beneficial effects both for cognition and the treatment of neurological conditions such as depression, attention deficit disorder, and epilepsy (Capovilla et al., 2016). Given that the classroom is a space that accommodates multiple realities, knowing the benefits and risks of physical exercise can also prevent stigmatization and propagation of myths (Capovilla et al., 2016).

Courses that provide knowledge updates and bring neuroscience closer to school allow teachers to have a new methodological and practical approach, boosting the teaching-learning process and ting the specific difficulties of their students. In this sense, it is important to disseminate actions in the field of professional qualification through neuroeducation in order to collaborate for the development of activities by other institutions and qualify more educators around the world.

\section{Methodology}

This article is a report that emphasizes teaching actions and experiences in the physical exercise and CNS component of the SCNAE in order to show the perception of teachers in charge of the discipline on the impact of this component for students. It is a descriptive study following the methodology of Pereira et al (2018) that started from the need to disseminate continuing education actions in neuroeducation.

The Physical Exercise and Nervous System component was offered in the first semester of the SCNAE.

The students enrolled in the discipline were basic education teachers and educational managers, and they were not asked to answer specific questionnaires or go through an interview.

The component was offered in a condensed form in six four-hour meetings for the specialization course students and divided into two modules.

\section{Module I (3 meetings)}

Initially, as the majority of students were teachers of basic education, we sought to conceptualize some relevant aspects of health related to the practice of physical activity, exercises and physiological adaptations, both acute and chronic, which were beneficial in childhood, and the relationship with neuroscience.

In the first half of the module, the importance of stimulating physical activity by the teacher for school-aged children was addressed, highlighting the current concern about the increase in sedentary lifestyle and the risk of associated chronic diseases (Lee et al., 2013). Then, we discussed experimental and epidemiological data (Ferreira et al., 2016; Feter et al., 2018; Hueston et al., 2017; Liao et al., 2015; Rombaldi et al., 2012) that related physical activity and school performance, emphasizing which strategies for practical activities we could incorporate in the routine of the school year that would include movement and decision-making, respecting limitations, biological individualities and being inclusive, as well as previous experiences that can commonly be found in a school group. Afterwards, a group dynamic was carried out, where academics proposed applicable activities that related the use of movement to solve mathematical or logical reasoning problems, thus stimulating creativity and knowledge exchange.

\section{Module II (3 meetings)}

In module two of the curricular component, more complex themes were addressed, such as the possible mechanisms of action by which PE acts in the CNS, as well as its role in the prevention and treatment of disorders that can affect brain activity, including Attention deficit hyperactivity disorder (ADHD), epilepsy, and depression.

In order to talk about the physiological effects on the CNS, the concepts of neuroplasticity were recovered, and to deepen this concept, articles on neurotrophic factors and their main effects on the brain were discussed. In addition, the concepts 
of oxidative stress and free radicals were addressed in order to ascertain what students knew about the topic and afterwards, evidence was presented of how PE increases antioxidant defenses and consequently reduces oxidative stress (Pilc, 2010; Radak et al., 2013).

Before talking about ADHD, the concept and types of attention and its importance for learning and memory were addressed. At this point, two activities were carried out with the group. The first consisted of a video called "Invisible Gorilla" The video at https://www.youtube.com/watch?v=vJG698U2Mvo. In the second activity, geometric figures with different shapes and colors were drawn. It was requested that when a pair of geometric figures with the same color was shown, everyone should get up from their chairs, and when a pair of the geometric figures of a different color was shown, everyone should be seated. The figures were shown 10 times for 3 seconds in different sequences. In the second step, students were asked to have their cell phones on their hands and open any application. The figures were exposed again.

ADHD was approached through scientific articles that describe the main neurophysiological changes and how PE can act as an adjuvant treatment for children with this disorder.

Epilepsy is due to an abnormal activity of nerve cells can have different manifestations (Abramovici \& Bagić, 2016). This disorder is still fraught with several dogmas, especially in relation to the practice of PE, so it is essential to guide and educate teachers so that they know how to handle a seizure and are safe to include children with epilepsy in scheduled physical activities. Video at https://www.youtube.com/watch?v=U6YCDuYg_6c, as a basis for discussion, in addition to scientific articles.

Depression is a serious disease in society nowadays and is associated with significant levels of morbidity and mortality in all populations (Avenevoli et al., 2015; Rakotoarisoa \& Angelova, 2018). During the module, first we talked about the pathological mechanism of depression and discussed about the imbalance of mood and emotions, in addition to the abnormalities in the limbic system and serotonin system that occur in depressive patients. Then, we exposed that the first episodes of depression generally occur during adolescence or young adulthood (Kessler et al., 2005).

In fact, earlier onsets of depression are associated with a worse clinical course over the lifespan, and in youth it is associated with drug and alcohol abuse, risky sexual behavior, suicide risk, poor academic outcomes and physical health problems (Donovan \& Spence, 2000; Kessler et al., 2001; Kessler et al., 2005).

Following this, we discussed about prevention programs, for example, universal prevention programs for youth that are typically delivered on a large scale in the school environment to every child in the grade (Neil \& Christensen, 2009). Schools are a place of learning and can offer a tremendous opportunity to provide young people with many of the skills and strategies that may protect against, or delay, the onset of emotional difficulties (Murray et al.). At this point, we introduced the subject of physical activity as a way to prevent depression. We started the discussion with the statement from the WHO that recommends the implementation of PE in the standard treatment of depression" (Kvam et al., 2016) and exposed different scientific articles about how PE induced beneficial neurophysiological changes to help children with this disorder.

To finish the module, the students were asked to develop games and PE for children with ADHD, epilepsy, and depression taking into account the respective care in the practice of activities for each group. Subsequently, the activities were presented and the care discussed in the large group.

\section{Results}

The majority of students of the SCNAE were basic education teachers, thus, PE was not a specific area of activity. Nevertheless, the first activities were interesting, as they enabled conceptual discussions and the assessment of everyone's perception of health, exercise and application with neuroscience. Everyone got involved, participating actively, and agreeing that it is an essential subject to be addressed in some way in early childhood, and that the teacher of initial grades has a fundamental 
role in this process.

The most striking moment of this first stage was the development of practical activities that included physical activity to perform a cognitive task. The activity was initially carried out in groups of three people and then shown to all academics in the group, which led to discussion of ideas, constructive criticism, and creation/proposals for new activities. The most recurrent themes included groups of children in obstacle races or in speed competition having to solve activities related to math or literacy. Finally, a closure was made where students reported that the activity was productive and that possibly some of the activities discussed would be put to practice in the school routine, emphasizing the importance of combating a sedentary lifestyle in early childhood.

The second stage aroused considerable discussion among the students. The practical activities of selective attention were very entertaining and generated a lot of debates, and teachers said that they intend to include the activities in their practice to explain to students how attention works and its importance for learning.

The epilepsy video generated a lot of curiosity since most students did not know about the different types of seizures that may exist, nor did they know how to react if they witnessed a student having a seizure.

The activity of planning games for children with ADHD, epilepsy and depression was very useful for the exchange of ideas and also to clarify doubts about which skills should be explored, and care to be taken in each game for each audience. Usually the same game can be applied to all children, however, specific care for different situations was highlighted.

The students demonstrated excellent engagement in the proposed activities and highlighted the importance of debating the topics covered. In addition to the participation of the group in the activities and the complexity of the debates, we considered a main positive outcome the interest of the students in applying the new knowledge in the practice of the schools where they work.

\section{Discussion}

The main purpose of educational neuroscience is to disseminate and consolidate a scientific basis in teaching and learning. The field uses the latest discoveries from neuroscience, psychology, and cognitive science to inform education professionals and consequently develop teaching strategies (Nouri \& Mehrmohammadi, 2012).

Teachers have expressed their desire to understand how the brain works and how learning occurs (Frith et al., 2011; Howard-Jones, 2014). In this sense, the SCNAE was created in 2015 at the Federal University of Pampa as a local demand from Basic Education teachers working in the city of Uruguaiana (South of Brazil) and region who had participated in extension and continuing education courses promoted by the POPNEURO Program.

Throughout the component we tried to constantly recover previous knowledge from students since the interaction of new knowledge with the existing ideas allows, through its cognitive activity, the learner to develop new meanings (Rakotoarisoa \& Angelova, 2018). Hence, knowledge is not transmitted, but actively built by individuals, what the subject already knows influences his learning (Ausubel et al., 1968). The main goal of the component was to discuss the effects of PE on the CNS. Most people probably already know that PE is necessary to preserve muscle strength, keep the heart strong, maintain a healthy body weight, and stave off chronic diseases such as diabetes. However, most people do not know that PE can also help boost thinking skills and be used as a tool in class to improve learning, memory and focus. During the course of the component this scientific knowledge was debated based on many shreds of evidence (Mandolesi et al., 2018).

It is fundamental to promote the children's physical fitness during primary school age, since it is well established that cognitive and motor skills follow similar developmental stages, with an accelerated progression in the years of kindergarten and elementary school (Ahnert et al., 2010; Breithecker \& Dordel, 2003). In fact, it has been suggested that motor development may 
have a positive relationship with cognitive and academic learning development (Abdelkarim et al., 2017; Bushnell \& Boudreau, 1993; Martin et al., 2010). Moreover, a systematic review and meta-analysis has found that an increase in physical activity in childhood and adolescence is associated with decreased depression symptoms (Korczak et al., 2017). Also, this beneficial effect of exercise in children and adolescents is regardless of intensity or type of physical activity (Larun et al., 2006).

In Brazil, children enrolled in kindergarten and elementary school in public schools do not have physical education classes with a physical education professional. The activities related to this curricular component are taught by the general teacher (pedagogue). Despite having adequate training that is directed to the teaching of children, teachers do not have specific and comprehensive disciplines related to "movement" or the comprehension about the benefits of PE to children's learning, and when they do, it is very superficial and limited to the field of education. In this sense, the continuing education courses in the neuroscience area are important to help them organize teaching strategies and optimize learning.

In addition, participants of a study "defining the boundaries for neuroeducation" highlight the importance of an "interdisciplinary collaboration" as the key to ensure a more prosperous future for education professionals (Nouri \& Mehrmohammadi, 2012). The interdisciplinary nature of neuroeducational studies implies conjoining a variety of perspectives and insights from relevant disciplines into a unified or coherent framework to solve complex problems whose solutions are beyond the scope of a single perspective or discipline (Nouri \& Mehrmohammadi, 2012).

Continuing education courses should be a concern for both individual teachers and the entire educational system. It is crucial that the teacher demonstrates that they have the opportunity to develop all of the expected competencies that are listed in local educational law, especially in elementary school (Café-Mendes et al., 2016). Studies have shown that access to a good quality preschool makes a difference in student learning outcomes in later stages (Campos et al., 2011; Draghici \& Welcomme; Neubauer et al., 1996)

\section{Final Considerations}

The students of the SCNAE were basic education teachers, thus, PE was not a specific area of activity. However, since the first activities, they showed interest in conceptual discussions and assessment of everyone's perception of health, exercise and application with neuroscience. Based on this, we consider there is a clear need to insert both the concept of neuroscience and PE in the daily lives of these education professionals. As well as promoting new workshops, they enable learning about neuroscience and PE to a new target audience of professors from different areas. For future studies, an investigation about how this class influences the professional practice nowadays for the teachers of this report of actions will be important. Besides, in another edition of the course, an investigation about teacher's knowledge previous and post-class will be interesting.

\section{Acknowledgments}

We gratefully thank CAPES (Coordination for the Improvement of Higher Education Personnel) for the financial support to the first author. Conflicts of interest: none.

\section{References}

Abdelkarim, O., Ammar, A., Chtourou, H., Wagner, M., Knisel, E., Hökelmann, A., \& Bös, K. (2017). Relationship between motor and cognitive learning abilities among primary school-aged children. Alexandria Journal of Medicine, 53(4), 325-331.

Abramovici, S., \& Bagić, A. (2016). Epidemiology of epilepsy. In Handbook of clinical neurology (138, 159-171). Elsevier.

Ahnert, J., Schneider, W., \& Bös, K. (2010). Developmental changes and individual stability of motor abilities from the preschool period to young adulthood. In Human development from early childhood to early adulthood (pp. 45-72). Psychology Press. 
Arce, J. P. S., Souza, M. M., de Vargas, L. d. S., \& Mello-Carpes, P. B. (2017). Divulgando a neurociência: ações para desmistificação de neuromitos. Revista ELO-Diálogos em Extensão, 6(1).

Arnsten, A. F., \& Rubia, K. (2012). Neurobiological circuits regulating attention, cognitive control, motivation, and emotion: disruptions in neurodevelopmental psychiatric disorders. Journal of the American Academy of Child \& Adolescent Psychiatry, 51(4), 356-367.

Ausubel, D. P., Novak, J. D., \& Hanesian, H. (1968). Educational psychology: A cognitive view.

Avenevoli, S., Swendsen, J., He, J.-P., Burstein, M., \& Merikangas, K. R. (2015). Major depression in the national comorbidity survey-adolescent supplement: Prevalence, correlates, and treatment. Journal of the American Academy of Child \& Adolescent Psychiatry, 54(1), 37-44. e32.

Breithecker, S. D.-D., \& Dordel, S. (2003). Bewegte Schule als Chance einer Förderung der Lern-und Leistungsfähigkeit. Haltung und Bewegung, 23(2), 5-15.

Bushnell, E. W., \& Boudreau, J. P. (1993). Motor development and the mind: The potential role of motor abilities as a determinant of aspects of perceptual development. Child development, 64(4), 1005-1021.

Café-Mendes, C. C., Righi, L. L., Calil-Silveira, J., Nunes, M. T., \& Abdulkader, F. (2016). Winter course in physiology: a successful example of continuing education for secondary school teachers in Brazil. Advances in physiology education, 40(4), 491-498.

Campos, M. M., Bhering, E. B., Esposito, Y., Gimenes, N., Abuchaim, B., Valle, R., \& Unbehaum, S. (2011). A contribuição da educação infantil de qualidade e seus impactos no início do ensino fundamental. Educação e Pesquisa, 37(1), 15-33.

Capovilla, G., Kaufman, K. R., Perucca, E., Moshe, S. L., \& Arida, R. M. (2016). Epilepsy, seizures, physical exercise, and sports: A report from the ILAE Task Force on Sports and Epilepsy. Epilepsia, 57(1), 6-12. https://doi.org/10.1111/epi.13261

Chaddock, L., Hillman, C. H., Buck, S. M., \& Cohen, N. J. (2011). Aerobic fitness and executive control of relational memory in preadolescent children. Medicine \& Science in Sports \& Exercise, 43(2), 344-349.

Donovan, C. L., \& Spence, S. H. (2000). Prevention of childhood anxiety disorders. Clinical psychology review, 20(4), 509-531.

Draghici, A. M., \& Welcomme, W. Kathy Sylva, Edward Melhuish, Pam Sammons, Iram Siraj-Blatchford and Brenda Taggart with Katalin Toth, Rebecca Smees, Diana. age, 11, 14.

Ferreira, R. W., Rombaldi, A. J., Ricardo, L. I. C., Hallal, P. C., \& Azevedo, M. R. (2016). Prevalence of sedentary behavior and its correlates among primary and secondary school students. Revista Paulista de Pediatria (English Edition), 34(1), 56-63.

Feter, N., Penny, J., Freitas, M., \& Rombaldi, A. (2018). Effect of physical exercise on hippocampal volume in adults: systematic review and meta-analysis. Science \& Sports, 33(6), 327-338.

Frith, U., Bishop, D., Blakemore, C., Blakemore, S.-J., Butterworth, B., \& Goswami, U. (2011). Neuroscience: implications for education and lifelong learning. The Royal Society.

Hillman, C. H., Erickson, K. I., \& Kramer, A. F. (2008). Be smart, exercise your heart: exercise effects on brain and cognition. Nature reviews neuroscience, $9(1), 58-65$.

Howard-Jones, P. (2014). Neuroscience and education: A review of educational interventions and approaches informed by neuroscience. Education Endowment Foundation, Millbank, UK.

Hueston, C. M., Cryan, J. F., \& Nolan, Y. M. (2017). Stress and adolescent hippocampal neurogenesis: diet and exercise as cognitive modulators. Translational psychiatry, 7(4), e1081-e1081.

Kessler, R. C., Avenevoli, S., \& Merikangas, K. R. (2001). Mood disorders in children and adolescents: an epidemiologic perspective. Biological psychiatry, 49(12), 1002-1014.

Kessler, R. C., Demler, O., Frank, R. G., Olfson, M., Pincus, H. A., Walters, E. E., Wang, P., Wells, K. B., \& Zaslavsky, A. M. (2005). Prevalence and treatment of mental disorders, 1990 to 2003. New England Journal of Medicine, 352(24), 2515-2523.

Korczak, D. J., Madigan, S., \& Colasanto, M. (2017). Children's physical activity and depression: a meta-analysis. Pediatrics, 139(4), e20162266.

Kvam, S., Kleppe, C. L., Nordhus, I. H., \& Hovland, A. (2016). Exercise as a treatment for depression: a meta-analysis. Journal of affective disorders, 202, 6786.

Larun, L., Nordheim, L. V., Ekeland, E., Hagen, K. B., \& Heian, F. (2006). Exercise in prevention and treatment of anxiety and depression among children and young people. Cochrane database of systematic reviews(3).

Lee, I.-M., Bauman, A. E., Blair, S. N., Heath, G. W., Kohl, H. W., Pratt, M., \& Hallal, P. C. (2013). Annual deaths attributable to physical inactivity: whither the missing 2 million? The Lancet, 381(9871), 992-993.

Liao, Y., Shonkoff, E. T., \& Dunton, G. F. (2015). The acute relationships between affect, physical feeling states, and physical activity in daily life: a review of current evidence. Frontiers in psychology, 6, 1975.

Mandolesi, L., Polverino, A., Montuori, S., Foti, F., Ferraioli, G., Sorrentino, P., \& Sorrentino, G. (2018). Effects of physical exercise on cognitive functioning and wellbeing: biological and psychological benefits. Frontiers in psychology, 9, 509.

Marré, A. (2017). Rural education at a glance. 
Martin, R., Tigera, C., Denckla, M. B., \& Mark Mahone, E. (2010). Factor structure of paediatric timed motor examination and its relationship with IQ. Developmental Medicine \& Child Neurology, 52(8), e188-e194.

Mello, G. N. d. (2000). Formação inicial de professores para a educação básica: uma (re) visão radical. São Paulo em perspectiva, 14(1), 98-110.

Murray, C., Barber, R., Foreman, K., Ozgoren, A. A., Abd-Allah, F., \& Abera, S. \& Vos, T.(2015). Global, regional, and national disability-adjusted life years (DALYs) for 306 diseases and injuries and healthy life expectancy (HALE) for 188 countries, 1990-2013: Quantifying the epidemiological transition. Lancet, 386, 2145-2191.

Neil, A. L., \& Christensen, H. (2009). Efficacy and effectiveness of school-based prevention and early intervention programs for anxiety. Clinical psychology review, 29(3), 208-215.

Neubauer, R., Davis, C., \& Espósito, Y. L. (1996). Avaliação do processo de inovações no ciclo básico e seu impacto sobre a situação de ensino-aprendizagem na região metropolitana de São Paulo. Estudos em Avaliação Educacional(13), 35-64.

Nouri, A., \& Mehrmohammadi, M. (2012). Defining the Boundaries for Neuroeducation as a Field of Study. Educational Research Journal, $27(1 / 2), 1$.

Pereira, A., Shitsuka, D., Parreira, F., \& Shitsuka, R. (2018). Metodologia da pesquisa científica.

Pessoa, L. (2009). How do emotion and motivation direct executive control? Trends in cognitive sciences, 13(4), 160-166.

Pickering, S. J., \& Howard-Jones, P. (2007). Educators' views on the role of neuroscience in education: Findings from a study of UK and international perspectives. Mind, Brain, and Education, 1(3), 109-113.

Pilc, J. (2010). The effect of physical activity on the brain derived neurotrophic factor: from animal to human studies. Journal of physiology and pharmacology, 61(5), 533-541.

Radak, Z., Marton, O., Nagy, E., Koltai, E., \& Goto, S. (2013). The complex role of physical exercise and reactive oxygen species on brain. Journal of Sport and Health Science, 2(2), 87-93.

Rakotoarisoa, M., \& Angelova, A. (2018). Amphiphilic Nanocarrier Systems for Curcumin Delivery in Neurodegenerative Disorders. Medicines (Basel), 5(4). https://doi.org/10.3390/medicines5040126

Rato, J. R., Abreu, A. M., \& Castro-Caldas, A. (2013). Neuromyths in education: What is fact and what is fiction for Portuguese teachers? Educational Research, $55(4), 441-453$

Rombaldi, A. J., Clark, V. L., Reichert, F. F., Araújo, C. L., Assunção, M. C., Menezes, A. M., Horta, B. L., \& Hallal, P. C. (2012). Incidence of school failure according to baseline leisure-time physical activity practice: Prospective study. Journal of Adolescent Health, 51(6), S22-S26.

Schwartz, M. (2015). Mind, brain and education: a decade of evolution. Mind, Brain, and Education, 9(2), 64-71.

Sibley, B. A., \& Etnier, J. L. (2003). The relationship between physical activity and cognition in children: a meta-analysis. Pediatric exercise science, 15(3), 243-256. 